\title{
AUTHOR INDEX Volume 11 (2006)
}

Abe, S., see Nakagawa, N.

Attar, K. H., see Imran, D.

Avarmidis, M., see Imran, D.

Başarir, K., Sağlik, Y., Yildiz, Y. and Tezen, E., Aneurysmal Bone Cyst of the Hand: A Report of Four Cases

Batistatou, A., see Mitsionis, G.

Bulstrode, N. W., see 0'Leary, E. J. P.

Canal, A., see Rocchi, L.

Catalano, F., see Rocchi, L.

Chow, S. P., see Rajesh, G.

Doi, K., see Kitajima, I.

Doi, R., see Ishida, K.

Egi, T., see Kazuki, K.

El Rassi, G. and Shah, S. A., Dynamic Scapholunate Dissociation in A Child

Estrella, E., see Kitajima, I.

Fanfani, F, see Rocchi, L.

Field, J., see Tomlinson, P. J.

Fujioka, H., Tanaka, J. and Tomatsuri, M., Scaphoid Non-Union After Simultaneous Fractures of the Scaphoid and the Capitate in a Child: A Case Report

Fujioka, H., see Ishida, K.

Fung, B. K.-K., see Rajesh, G.

Gavriilidis, I., see Mitsionis, G.

Gould, E. S., see Mangrulkar, V. H.

Gschwind, C., see 0'Leary, E. J. P.

Haga, N., Masuda, K. and Takikawa, K., Osteochondral Destruction in the Hand Following Bee Stings: A Case Report of an Infant

Hattori, T., see Tatebe, M.

Hattori, Y., see Kitajima, I.

Hirata, H., see Imaeda, T.

Hirata, H., see Tatebe, M.

Ho, S. T., see Koo, S. C.

Hooper, G., see Jianmongkol, S.

Ignatiadis, I. A., see Yiannakopoulos, C. K.

Ijichi, M., see Imaeda, T.

Ikeda, M., see Ueda, D.

Imaeda, T., Hirata, H., Toh, S., Nakao, Y., Nishida, J., Ijichi, M. and Nagano, A., Comparative Responsiveness of Japanese Versions of the DASH and SF-36 Questionnaires and Physical Measurement to Clinical Changes After Carpal Tunnel Release

Imran, D., Avarmidis, M. and Attar, K. H., An Anomalous Muscle Mimicking a Dorso-Radial Ganglion as a Cause of Radial Wrist Pain
$1 \& 2(2006) 71-75$

$1 \& 2$ (2006) 47-49

$1 \& 2$ (2006) 47-49

$1 \& 2$ (2006) 35-41

$1 \& 2$ (2006) 89-91

3 (2006) 147-149

$1 \& 2$ (2006) 21-26

$1 \& 2$ (2006) 21-26

$1 \& 2$ (2006) 83-88

3 (2006) 103-107

$1 \& 2$ (2006) 43-45

$1 \& 2$ (2006) 1-4

$1 \& 2$ (2006) 55-57

3 (2006) 103-107

$1 \& 2$ (2006) 21-26

1\&2 (2006) 5-8

3 (2006) 151-152

$1 \& 2$ (2006) 43-45

$1 \& 2$ (2006) 83-88

1\&2 (2006) 89-91

1\&2 (2006) 51-53

3 (2006) 147-149

3 (2006) 143-145

$1 \& 2$ (2006) 9-14

3 (2006) 103-107

$1 \& 2$ (2006) 27-33

$1 \& 2$ (2006) 9-14

$1 \& 2$ (2006) 67-70

$1 \& 2$ (2006) 93-99

3 (2006) 159-162

$1 \& 2$ (2006) 27-33

1\&2 (2006) 59-62

$1 \& 2$ (2006) 27-33

$1 \& 2$ (2006) 47-49 
Inocentes, Jr., E. M., The Early History of Hand Surgery in the Philippines and Highlights in My Experience at the National Orthopaedic Hospital Mandaluyong and the Our Lady of Lourdes Hospital, Manila

3 (2006) 109-133

$1 \& 2(2006) 83-88$

Ishida, K., Fujioka, H. and Doi, R., Acute Rupture of Extensor Pollicis Longus Tendon Due to Avulsed Fracture of the Second Metacarpal Base: A Case Report

Iwata, Y., see Tatebe, M.

Jianmongkol, S., Hooper, G., Kowsuwon, W. and Thammaroj, T., A Comparative Biomechanical Study of the Looped Square Slip Knot and the Simple Surgical Knot

Jidpugdeebodin, S., see Leechavengvongs, $S$.

Kazuki, K., Egi, T., Okada, M. and Takaoka, K., Clinical Outcome of Extrasynovial Steroid Injection for Trigger Finger

Kitajima, I., Doi, K., Hattori, Y., Takka, S. and Estrella, E., Evaluation of Quality of Life in Brachial Plexus Injury Patients After Reconstructive Surgery

Koo, S. C. and Ho, S. T., Delayed Rupture of Flexor Pollicis Longus Tendon After Volar Plating of the Distal Radius Kowsuwon, W., see Jianmongkol, S.

Kozuki, K., see Sakamoto, K.

Leechavengvongs, S., Jidpugdeebodin, S. and Milindankura, S., Necrotising Fasciitis Causing Compartment Syndrome of the Forearm and Septic Shock Due to Vibrio vulnificus: A Case Report

Mangrulkar, V. H., Gould, E. S. and Miller, F., Digital Papillary Adenocarcinoma: A Case Report

Masuda, K., see Haga, N.

Milindankura, S., see Leechavengvongs, S.

Miller, F., see Mangrulkar, V. H.

Mitsionis, G., Pakos, E. E., Gavriilidis, I. and Batistatou, A., Cubital Tunnel Syndrome Due to Giant Cell Tumour of Tendon Sheaths

Miura, Y., see Nakagawa, N.

Nagano, A., see Imaeda, T.

Nakagawa, N., Saegusa, Y., Abe, S., Miura, Y. and Yoshiya, S., The Effectiveness of RA Wrist Fusion Using Beta-TCP Without Autogenous Iliac Bone Grafting: A Report of Four Cases

Nakamura, R., see Tatebe, M.

Nakao, Y., see Imaeda, T.

Nishida, J., see Imaeda, T.

Oka, Y., see Ueda, D.

Okada, M., see Kazuki, K.

O'Leary, E. J. P., Bulstrode, N. W. and Gschwind, C., Acute Bilateral Forearm Compartment Syndrome of Unknown Aetiology

Pakos, E. E., see Mitsionis, G.

Pelaez, J., see Rocchi, L.

Porter, M., see Roberts, C.

Rajesh, G., Ip, W.-Y., Chow, S. P. and Fung, B. K.-K., Treating Deep-seated Mycobacterium marinum Infection in the Hand: A Report of Three Cases

Roberts, C., Porter, M., Wines, A. P. and Shadbolt, B., The Association of Scapho-Trapezio-Trapezoid Osteoarthrosis and Scapholunate Dissociation

Rocchi, L., Canal, A., Pelaez, J., Fanfani, F. and Catalano, F., Results and Complications in Dorsal and Volar Wrist Ganglia Arthroscopic Resection

Saegusa, Y., see Nakagawa, N.

Sağlik, Y., see Başarir, K.

Sakamoto, K., Kozuki, K. and Shakya, I. M., Simultaneous Fractures of Distal and Proximal Phalanges of the Thumb, Trapezium and Carpal Scaphoid of the Ipsilateral Hand: A Case of Very Unusual Combination of Fractures

Shadbolt, B., see Roberts, C.

Shah, S. A., see El Rassi, G.

Shahane, S. A., see Srikanth, K. N.

Shakya, I. M., see Sakamoto, K.

Slesarenko, Y., Minimally Invasive Technique for Finger Flexor Pulley Reconstruction
$1 \& 2(2006) 43-45$

$1 \& 2(2006) 9-14$

$1 \& 2(2006) 93-99$

$1 \& 2(2006) 77-82$

$1 \& 2(2006) 1-4$

3 (2006) 103-107

$1 \& 2(2006) 67-70$

$1 \& 2(2006) 93-99$

$1 \& 2$ (2006) 63-66

$1 \& 2$ (2006) 77-82

$1 \& 2$ (2006) 51-53

3 (2006) 143-145

$1 \& 2$ (2006) 77-82

$1 \& 2$ (2006) 51-53

$1 \& 2$ (2006) 89-91

$1 \& 2$ (2006) $71-75$

$1 \& 2$ (2006) 27-33

$1 \& 2$ (2006) $71-75$

$1 \& 2$ (2006) 9-14

$1 \& 2$ (2006) 27-33

$1 \& 2$ (2006) 27-33

$1 \& 2$ (2006) 59-62

$1 \& 2$ (2006) 1-4

3 (2006) 147-149

$1 \& 2$ (2006) 89-91

$1 \& 2$ (2006) 21-26

3 (2006) 135-141

$1 \& 2$ (2006) 83-88

3 (2006) $135-141$

$1 \& 2$ (2006) 21-26

$1 \& 2$ (2006) 71-75

$1 \& 2$ (2006) 35-41

$1 \& 2$ (2006) 63-66

3 (2006) 135-141

$1 \& 2$ (2006) 55-57

$1 \& 2$ (2006) 15-19

$1 \& 2$ (2006) 63-66

3 (2006) 153-157 
Srikanth, K. N., Shahane, S. A. and Stilwell, J. H., Modified Matched Ulnar Resection for Arthrosis of Distal Radioulnar Joint in Rheumatoid Arthritis

$1 \& 2(2006) 15-19$

Stilwell, J. H., see Srikanth, K. N.

$1 \& 2(2006) 15-19$

$182(2006) 1-4$

Takaoka, K., see Kazuki, K.

3 (2006) $143-145$

Takikawa, K., see Haga, N.

3 (2006) 103-107

Takka, S., see Kitajima, I.

3 (2006) 151-152

Tatebe, M., Hirata, H., Iwata, Y., Hattori, T. and Nakamura, R., Limited Wrist Arthrodesis versus Radial Osteotomy for Advanced Kienböck's Disease — For a Fragmented Lunate

Tezen, E., see Başarir, K.

$1 \& 2(2006) 9-14$

$1 \& 2(2006) 35-41$

$1 \& 2(2006) 93-99$

Thammaroj, T., see Jianmongkol, S.

$1 \& 2(2006) 27-33$

Toh, S., see Imaeda, T.

3 (2006) $151-152$

$182(2006) 5-8$

Tomlinson, P. J. and Field, J., Morbidity of Hand and Wrist Ganglia

Ueda, D., Ikeda, M. and Oka, Y., Locking of the Metacarpophalangeal Joint of the Thumb by a Loose Body: A Case Report

Wines, A. P., see Roberts, C.

Yiannakopoulos, C. K. and Ignatiadis, I. A., Transdermal Anaesthesia for Percutaneous Trigger Finger Release

Yildiz, Y., see Başarir, K.

Yoshiya, S., see Nakagawa, N.

$1 \& 2(2006) 59-62$

3 (2006) 135-141

3 (2006) 159-162

$1 \& 2(2006) 35-41$

$1 \& 2(2006) 71-75$ 